\title{
An Analysis of Indonesia's 2013 EFL Curriculum and Turkey's National English Language Curriculum for Secondary Schools
}

\author{
Suci Noer Wulan Sari \\ Universitas Pendidikan Indonesia \\ e-mail: sucinoerwulansari@student.upi.edu \\ Niken Anastasia Kusuma Wardani \\ Universitas Pendidikan Indonesia \\ e-mail: niken.anastasia@student.upi.edu
}

\begin{abstract}
:
Indonesia and Turkey have experienced educational reforms for decades, for instance in constructing EFL curriculum. Educational reforms could be performed to address a certain problem encountered by a nation and to better the quality of education. Therefore, there emerged a need to analyse the EFL curricula designed for secondary schools in both countries to identify the commonalities and differences considered for a better improvement in education quality. Thus, the present study was aimed at analysing Indonesia's 2013 EFL Curriculum and Turkey's National English language Curriculum for secondary schools: the rationale, aims and organization (instructional design, instructional materials, and assessment). The study employed a qualitative descriptive design using document analysis to analyse some curricula documents. The findings revealed the commonalities lie in learner-centeredness view and the main goal of EFL curriculum. However, the differences lie in the instructional design, materials, and assessment. Given that Indonesia may adopt technology-enhanced materials and assessments to promote effective, engaging, and enjoyable teaching and learning. It is suggested for further studies to employ interviews with teachers and students to see how they perceive the curriculum they have experienced, and observation to see the actual implementation of the curriculum employed.

Keywords: EFL Curriculum, Indonesia's 2013 EFL Curriculum, Turkey's National English language Curriculum
\end{abstract}




\section{Introduction}

Each nation undoubtedly has its own challenges in every aspect of life including fostering better education for a better future for its citizen. Since there is a challenge in enhancing a better education, a nation needs to address a certain way called curriculum. A curriculum is believed as one of the main concerns in educational field ( $\mathrm{Su}, 2012)$. It acts as a choice as to how to deal with the education of students (Posner, 1992). Additionally, Prideaux (2003) pointed out that a curriculum expresses educational ideas in practice. A curriculum represents how certain educational ideas are proposed in order to respond to a certain problem.

Indonesia and Turkey are two of developing countries that have been struggling to enhance their education quality. In PISA 2015 results, Indonesia ranked $62^{\text {nd }}$ with mean score 397 in reading performance, meanwhile Turkey ranked above with mean score 428 (OECD, 2016). The result of reading performance indicates and can predict academic performance as well (Chege, 2012). Good academic performance result thus can be seen from a curriculum set in a nation since it prepares students to face the future (Ornstein, 2011) including their academic life. Both countries certainly have their own curriculum, for example to respond to problems formulated and struggle to enhance their education quality. They also have experienced the curricula reforms for decades considering for a better education quality.

Indonesia has gone through the curricula reforms for decades. The development reoccurring is followed by the rationale as well. For instance, in 2006 the curriculum developed was school-based curriculum with the rationale which was decentralizing the curriculum by giving autonomy to schools to develop the curriculum based on their needs. The recent curriculum implemented in Indonesia is 2013 Curriculum been recently revised to achieve the goal of national education. To achieve the goal of national education, there is a need to set passing competence standard which is one of the criteria of the qualification of passing skills: attitudes, knowledge, and skills. To attain the passing skills based on range and certain education level, standard of content, which is the criterion of the scope of materials and competence levels of learners, needs to be set as well. Additionally, the curriculum is developed for preparing Indonesia's Golden Generation in 2045 (Ministry of Education and Culture of Indonesia, 2016). Specifically, in the revision of 2013 EFL Curriculum, the rationale is the course is still aimed at developing learners' communicative skills both written and spoken.

Similarly, Turkey has also experienced curricula reforms. Recently, Turkey's Ministry of National Education (MONE) has geared up for a curriculum overhaul that will be intended to simplify content while increasing students' analytical skills (Hurriyet Daily News, 2017). However, considering a curriculum renewal is still in the preparation, the National Curriculum is widely implemented in subject matters including English language taught nationwide. The EFL curriculum implemented is based on educational levels set there: the $2^{\text {nd }}-8^{\text {th }}$ grades English Curriculum (for primary schools), and the $9^{\text {th }}-12^{\text {th }}$ grades English language Curriculum (for secondary schools) though generally both can be simply called National English language Curriculum. MEB-TTKB (2014) pointed out that Turkey's MONE updated 
and revised the $2^{\text {nd }}-8^{\text {th }}$ grades English language Curriculum in 2013; so that, it called for the renewal of the $9^{\text {th }}-12^{\text {th }}$ grades English language Curriculum as well. The New $9^{\text {th }}-12^{\text {th }}$ grades English language Curriculum (NELC) followed the same communicative focus in the New $2^{\text {nd }}-8^{\text {th }}$ grades English language Curriculum. The new English curriculum is thus intended to foster learners' communicate skills.

Three studies on analysing two or more EFL curricula have been conducted such as the works of Istiqomah (2013), Kondakçı (2014), and Suarman, (2011). Kondakçı (2014) conducted a study on comparing national and international English curricula for high schools in Turkey. Istiqomah (2013) did a comparison study of Australian and Indonesian English Curriculum for upper primary school. Suarman (2011) tried to analyse Indonesia's 2004 English Curriculum and Philippine's 2011 Secondary English Curriculum. Most of the studies revealed the characteristics of curriculum, commonalities and differences. Compared to the previous studies, the present study was intended to analyse the recent Indonesia's 2013 EFL Curriculum and Turkey's National English language Curriculum: the $9^{\text {th }}-12^{\text {th }}$ grades English language Curriculum (NELC) designed for secondary schools. It was focused on analysing the rationale, aims, and organization (instructional design, instructional materials, and assessment). It also identified commonalities and differences shared between the curricula for a better improvement in education in the future.

Given that it is hoped that the present study would serve to provide information about Indonesia's 2013 EFL Curriculum and Turkey's National English language Curriculum designed for secondary schools in both countries. Moreover, the study might be useful for those who plan to conduct researches on analysing two EFL curricula implemented in two or more countries to seek the commonalities and differences that could be adapted for classroom practices and considered for better improvement in education in the future.

\section{Literature Review}

\subsection{Curriculum}

Curriculum is derived from the Latin word "currere" which means "to track or race course" (Pratt, 1994; Barrow and Milburn, 1990; in Su, 2012). It is believed as one of the big concerns in educational field. Curriculum also prepares students to face the future (Ornstein, 2011). Posner (1992) believed that a curriculum acts as a choice as to how to deal with the education of students. Moreover, it represents how certain educational ideas are expressed in practice (Prideaux, 2003) in order to respond to a certain problem. However, the problem formulated is believed may affect but does not decide the curriculum. In educational field, a curriculum thus can be defined as a framework or guidance to guide teachers and educational stakeholders in deciding what to teach, how to teach, when to teach, what is the impact of the teaching, and how to assess and evaluate the teaching and learning. In developing a curriculum, there are some considerations: goals, contents and sequencing, effective teaching, assessment, and evaluation (Richards, 2001; Nation and Macalister, 2010). 


\subsubsection{Goals}

Richards (2001) pointed out that the terms goal and aim are used interchangeably to address a description of the broad purposes of a curriculum. A curriculum sets goals in order to decide why a course is being taught and what learners need to achieve from it (Nation and Macalister, 2010). Goals can be written in general terms and be given more explanation when justifying the content of the course. It is essential to have a precise goal in order to consider the content of the course, decide the focus in presentation, and guide assessment.

\subsubsection{Planning course contents, sequencing, and selecting syllabus framework}

\subsubsection{The course rationale}

Rationale is defined as justification, reasons, or intentions for certain set of actions (Brown, 1994). In course development, the course rationale is a starting point to be discussed. It justifies the course by addressing the whole point (Nulty, 2012). The course rationale explains the beliefs, values and goals behind the decision making for the course. Mostly, it is a two- or three- paragraph statement that has been discussed by those involved in planning and teaching a course.

\subsubsection{Describing the entry and exit level}

The entry level is the level which at the program will start and the exit level is the level which learners are considered to reach at the end of the course. In order to enter a language program and targeted performance or proficiency levels at the end of the course, more detailed information about students' proficiency levels are required. Mostly, the information on students' entry level can be gathered from their results on international proficiency tests such as TOEFL or IELTS. Information gathered helps enabling the target level of the course program to be evaluated and may need change of the program's objectives if they are seen too low or too high to achieve.

\subsubsection{Choosing course content}

A course has to be designed in order to address a particular set of needs and provide a given set of course objectives. In decision making of choosing course content, the decision they make reflect their assumptions about the nature of language, language use, and language learning, what the most substantial elements or units of language are, and how these can be arranged as an efficient and effective basis for second language learning.

\subsubsection{Determining the scope and sequence}

Scope has something to do with the breadth and depth of coverage of items (Richards, 2001). Course planners need to determine how much of the coverage of that topic will be included, for example, two, four, or six class periods given to the topic. Meanwhile, the sequencing of the content involves considering which content needed early in the course and which offers a basis for things that will be studied later. Sequencing can be categorized into simple to complex, chronology, need, prerequisite learning, whole to part or part to whole, and spiral. 


\subsubsection{Selecting syllabus framework}

A syllabus describes what will or what should be learnt (Hutchinson and Waters, 1987). It explains the key components that will be implemented in developing a language course and serves the foundation for its instructional focus and content. Designing a language syllabus can be a daunting task since there are number of types of syllabus, issues, also rationale for adopting materials for a syllabus (Tabari, 2013). Richards (2001) stated that commonly in choosing a certain syllabus framework for a course, there are some factors influencing planner in their decision making such as: knowledge and beliefs, research and theory, common practice, and trends. There are some types of syllabus such as:

- Grammatical (or structural) syllabus - organized around grammatical items.

- Lexical syllabus - which a target vocabulary is identified as the focus to be taught.

- Functional syllabus - developed around communicative functions, for example: requesting, agreeing, suggesting, and complaining.

- Situational syllabus - organized around the language required for the various situations, for example: at the airport or at a restaurant.

- Topical or content-based syllabus - developed around topics, themes, or other parts of content.

- Competency-based syllabus - focuses on a specification of the competencies students should achieve in relation to certain situations and activities.

- Skills syllabus - focuses on skills in using a language for purposes.

- Task-based syllabus - designed to facilitate second language learning in which tasks are given to learners in order to complete them in the target language.

- Text-based syllabus - designed around texts and samples of extended discourse.

\subsubsection{Developing instructional blocks}

Instructional blocks offer instructional focus of the course either specifically or generally. Specific means it is a single lesson while general means it offers a unit of work involving some lessons. Generally, two instructional blocks implemented are designing by modules (designed as independent learning sequence along with its objectives) and by units (designed as a group of lessons for a single instructional focus).

\subsubsection{Providing for effective teaching}

In supporting schools to achieve their goals, effective teaching should be provided and sustained in a language program. Effective teaching is attained not only as a result how surpassed good teaching takes place, or in other words, how well teachers teach in the class but through establishing situations and work environments that can promote good teaching (Richards, 2001). In providing for effective teaching, there are some challenges: institutional factors (e.g. organizational culture, quality indicators, and a sound curriculum); teacher factors (e.g. skills and qualifications, adequate materials, and course guides); teaching factors (e.g. teaching models and principles, observation, and shared planning); and learner factors (e.g. understanding of the course, views of learning, learning styles, and motivation). 


\subsubsection{Assessing and evaluating}

An essential continual part of the curriculum development process is to assess how well the aims are attained (Nation and Macalister, 2010). The assessment process involves the use of tests. Testing would help teachers gather information about the learners' learning progress. Afterwards, information gathered from the assessment process can contribute to the evaluation of the course. The evaluation is carried out either to continue the course or not, or to consider some improvements in the course. Furthermore, ongoing evaluation is needed to have a better curriculum design.

\subsection{Studies on Analysis of EFL Curricula}

Kondakçı (2014) analysed five national and international English curricula for high schools in Turkey. The study revealed that the five EFL curricula share similarities in evaluation using scientific-positivistic model, meanwhile the differences lie in educational philosophies, intent, content, implementation, and assessment. Istiqomah (2013) did a comparison study of Australian and Indonesian English Curriculum for upper primary school. The findings revealed that the curricula tend to share more differences than commonalities in terms of goal, standards of learning, teaching and learning activities. It further suggested that Australian classroom practices such as seat arrangement, furniture and class decoration might be adapted to Indonesian school context. Meanwhile, Suarman (2011) compared Indonesia's 2004 English Curriculum to Philippine's 2011 Secondary English Curriculum. The findings revealed that the commonalities lie in goal formulation, approaches, teaching process, and evaluation. Meanwhile, the differences are the great design of the curricula, organization of materials, teaching process, and evaluation. Philippine's 2010 SEC is believed more complete and complex than Indonesia's 2004 CBC. Accordingly, those studies tried to analyse two or more curricula which certainly share commonalities and differences in some parts of the structure, for example. Given that analysing curricula is considered as one of the ways to get more insight into curricula designed and implemented, give implications for future practice and research, and potential consideration for better improvement in education planning.

\section{Research Methodology}

\subsection{Design}

Since the study tried to analyse Indonesia's 2013 EFL Curriculum and Turkey's National English language Curriculum for secondary schools, a qualitative descriptive was employed to capture a phenomenon or individuals (Zacharias, 2012) which is about the curricula in terms of the rationale, aims and organization (instructional design, instructional materials, and assessment). Moreover, it could serve as "a rich description of the experience depicted in easily understood language" (Sullivan-Bolyai, Bova and Harper, 2005, as cited in Mendez-Shannon, 2010). Furthermore, it involved document analysis to analyse the rationale, aims, organization of the curriculum, commonalities, and differences shared between the two curricula. 


\subsection{Data Collection}

The study employed some documents, taken from the websites of the institutions, such as Ministry of Education and Culture Regulation of Indonesia No. 21 Year 2016 on standard of content for primary and secondary education, Ministry of Education and Culture Regulation of Indonesia No. 69 Year 2013 on the basic framework and curriculum structure of senior high schools, 2013 EFL syllabi, and “Ortaöğretim İngilizce Dersi $(9,10,11$ ve 12. Sinıflar) Öğretim Programı", or Secondary English Course (9th, 10th, 11th and 12th Grades) Curriculum by T.C. Millî Ĕ̆itim Bakanlı̆̆l, Talim ve Terbiye Kurulu Başkanlı̆̆l (MEB-TTKB), or Republic of Turkey, Ministry of National Education, Education and Training Boards (2014).

\subsection{Procedures}

Initially, the data was gathered from some documents regarding Indonesia's 2013 EFL Curriculum and Turkey's National English language Curriculum: the New $9^{\text {th }}$ $12^{\text {th }}$ grades English language Curriculum (NELC). Afterwards, the rationale, aims, and organization of the curriculum of 2013 EFL Curriculum and NELC were analysed. Given that the commonalities and differences shared between the two curricula were discussed.

\subsection{Data analysis}

The data gathered from the websites were analysed qualitatively. The data analysis employed the steps of Miles and Huberman's (1984) interactive model: data reduction, data display, and conclusion drawing/verification. Data reduction was done by focusing on the themes: the rationale, aims, and organization of the two curricula. Then, the data was explained based on the focused themes. And the data was concluded to see the commonalities and differences shared by the two curricula.

\section{Findings and Discussions}

Since the study was focused on analysing Indonesia's 2013 EFL Curriculum and Turkey's National English language Curriculum for secondary schools, and following what is suggested in curriculum development, some considerations to look up are goals, contents, and sequencing, effective teaching, assessment, and evaluation (Richards, 2001; Nation and Macalister, 2010). Thus, the analysis was mainly focused on the rationale, aims, organization (instructional design, instructional materials, and assessment) and tried to seek commonalities and differences shared between the curricula for a better improvement in education in the future as stated earlier in the paper.

\subsection{Analysis of Indonesia's 2013 EFL Curriculum for secondary schools}

\subsubsection{The rationale}

The new curriculum implemented in Indonesia is 2013 Curriculum that has been recently revised for the rationale: to achieve the goal of national education. To achieve the goal of national education, passing competence standard (one of the criteria of the passing skills qualification: attitudes, knowledge, and skills), needs to 
be set. To achieve the passing skills based on range and particular education level, standard of content needs to be set as well. Standard of content includes the scope of materials and competence levels of learners. Moreover, the curriculum is developed since Indonesia is preparing Golden Generation in 2045 (Ministry of Education and Culture Regulation, 2016).

2013 EFL Curriculum implemented in senior high schools in Indonesia was also revised. The EFL Curriculum is the continuation of English curriculum employed in junior high schools. In this level, language components such as vocabulary, pronunciation, grammar and other components are taught even though it is seen complex since there are differences between English language and learners' first language, Bahasa Indonesia. Moreover, the learning is more focused on the texts meaning that teachers will facilitate students to experience kinds of English texts for the rationale that students would reflect factual, conceptual, and procedural knowledge through speaking, listening, reading, and writing activities. Additionally, the rationale behind employing texts for the learning is to respect religious and social values in effective interaction with the society.

\subsubsection{The aims}

According to the Ministry of Education and Culture of Indonesia (2016), 2013 Curriculum is aimed at preparing Indonesian people to have life skills as a pious, productive, creative, and innovative individual and citizen, and capable of giving contribution to society, nation, and world civilization. Meanwhile, 2013 EFL Curriculum is intended to foster learners' language competence: communicative skills. The learners are expected to be able to communicate in various contexts both spoken and written using higher complex materials than the ones learnt in junior high school level. Generally, the communicative skills expected are reflected from three kinds of texts: interpersonal, transactional, and functional both spoken and written by using various texts in coherent and cohesive ways. Specifically, they are expected: (1) to indicate good behaviours in personal, social cultural, academic, and professional environments; (2) to identify social function, text structures, language features of short texts on life in general and learners' daily life; (3) to communicate in interpersonal, transactional, functional ways about one's self, family, people, animals, concrete and abstract things close to life and learners' daily life at home, school, and society, and related to other subject matters and works; and (4) to understand meanings, be fluent, and organize spoken and written texts by using sequenced text structures and accurate language features.

The learning still employs the same approach: genre-based approach referring to language functions and use. Genre serves to provide the framework of text structures: purpose and social function reflected by its text structure, and language features. Texts are studied not for the outcomes, but it is rather used as the tool to conduct activities in daily life situations. By employing genre-based approach in English learning, that will facilitate other subjects as well. For example, in explanation or exposition text, students will find it easy to widen their knowledge of materials on international scale. Moreover, by studying descriptive text, students would develop their knowledge in Arts and Culture to promote tourisms in 
Indonesia. Given that it is believed that genre-based approach is relevant to be implemented in the learning process to develop students' communicate skills.

\subsubsection{The organization of the curriculum}

\subsubsection{Instructional design}

Since the learning employs genre-based approach, instructional designed is mostly text-based since the learning is intended to foster students' communicative skills through the use of various texts. The format of the instructional design is suggested to be simplified to effectively focus on the scope of the materials will be taught. Moreover, it considers sequencing of materials and competences. The syllabus design developed is intended to be teachable, learnable, measurable, and worth to learn as the consideration for learners' life and continuing education (Ministry of Education and Culture of Indonesia, 2016). Given that instructional designers need to determine the syllabus framework adjusted to the genre-based approach employed in the learning in order to help learners achieve the aim of the curriculum: developing communicative skills.

\subsubsection{Instructional materials}

Indonesia's 2013 EFL Curriculum for senior high schools suggests materials around texts (interpersonal, functional, and transactional) and language functions. As it is suggested by Ministry of Education and Culture of Indonesia (2016), interpersonal texts include greeting, appraising, and responding; transactional texts offers one's self by considering grammar e.g. pronouns, asking for and giving opinions considering modality: should and can, offering helps, conditional sentences. Specific functional texts include announcement, song lyrics, invitation, personal letter, application letter, and manual. And functional texts involve text types: descriptive, recount, narrative, narrative, analytical exposition, explanation, procedure, and news items. In EFL syllabus guidance, teachers are suggested to sequence the materials based on basic competence and core standard. This is in accordance with Richards (2001) that contents should be sequenced; so that the learning would be meaningful since the students can associate the new material to the previous ones.

\subsubsection{Assessment}

Generally, 2013 Curriculum emphasizes on authentic assessment. According to The Regulation of the Minister of Culture and Education of the Republic of Indonesia Number 104 Year 2014 as cited in Mardjuki (2018), authentic assessment is a type of assessment employed to assess students' knowledge, skills, and behaviour which are obtained from the learning process in achieving an assignment in a real context happening. The assessment requires teachers to assess learners' spiritual and social values, knowledge and skills with using the scale 0-100. Authentic assessments include performance, project, product, paper and pen, portfolio, behaviour, and selfassessment. The assessment of process and learning outcomes are conducted based on the principles: (1) integrative - including characters, knowledge, and skills to use English both spoken and written contextually in accordance with its purpose and social function; (2) assessment of characters (such as honesty, disciplinary, 
tolerance, cooperation, and manner) are focused on visible ones seen during learning process on communication both spoken and written. Considering the types of authentic assessments suggested above, teachers may assess their students' English learning progress by employing those to know how well the aims are achieved.

\subsection{Analysis of Turkey's National English language Curriculum: the New $9^{\text {th }}$. $12^{\text {th }}$ Grades English Language Curriculum (NELC)}

\subsubsection{The rationale}

In Turkey, the English teaching program has been justified in accordance with the general goals of Turkish National Education as explained in the Basic Law of the National Education No. 1739. Additionally, since Turkish Ministry of National Education and Boards of Education and Training made the updates and revisions in the new $2^{\text {nd }}-8^{\text {th }}$ grades English language Curriculum in 2013, there emerged a demand for updating and revising the $9^{\text {th }}-12^{\text {th }}$ grades English language Curriculum as well (MEB-TTKB, 2014).

The New $9^{\text {th }}-12^{\text {th }}$ grades English language Curriculum (NELC) followed the same communicative focus proposed in the New $2^{\text {nd }}-8^{\text {th }}$ grades English language Curriculum since lack of effective communicative competence has become the issue of many English language learners in Turkey. Students in $9^{\text {th }}-12^{\text {th }}$ grades in English classes are expected to be effective communicators of English. However, since students have different ages and learning needs, the integration of four English skills are emphasized in the new curriculum. Moreover, they are expected to be autonomous learners. They need to be more responsible and conscious about the transference of their native language to their second language learning experience. Given that the curriculum covers limited study of some complex language structures. Further, more instructional technology tools are employed in the language teaching and learning process to consider the real-life experiences of learners; so that the teaching and learning would be stimulating, motivating, and enjoyable.

\subsubsection{The aims}

Generally, the $9^{\text {th }}-12^{\text {th }}$ grades English language Curriculum was developed to meet the language needs of both English teachers and learners in Turkey. However, the New $9^{\text {th }}-12^{\text {th }}$ grades English language Curriculum (NELC) is rather aimed at precisely providing specific enough guidance to English teachers, administrators, and material designers to have a clear framework for providing effective English language teaching and learning experiences. Given that English teachers can broadly, adaptably and creatively develop the content to fulfil their learners' individual needs. Specifically, MEB-TTKB (2014) pointed out that the main goal of the NELC in Turkey is to engage English language learners in inspiring, encouraging, and enjoyable learning environments in order to support them to be autonomous, productive, and successful individuals who are able to effectively, fluently, and accurately communicate in English. This is in accordance with what Richards (2001) suggested that one of the main concerns in developing a curriculum, educational stakeholders need to establish learning situations and work 
environments that promote effective teaching and learning. By providing a good environment, the main goal of NELC which is fostering learners' communicative skills can be achieved.

MEB-TTKB (2014) further suggested that in order to achieve the main goal of the NELC, it is believed that the collaboration and support of all parties among the leading stakeholders in the education system (including administrators, teachers, material designers, and learners) are needed. This is in line with Richards (2001) who stated that there should be a determination of all factors: institutions, teacher, teaching, and learners that would contribute to the success of achieving the aims. Here, in the implementation of the NELC, administrators' support is significant in applying assessment. Assessment strategies and styles should meet the nature of language learning process which includes alternative assessment methods to employ. Teachers also have roles in the implementation of the NELC by supporting and committing to it. It is essential for them to learn about the main principles of the curriculum, consider the rationale behind the principles, and reflect the principles with suitable teaching techniques in order to support their learners to effectively, fluently, and accurately communicate in English. Additionally, material designers play a significant role in implementing the NELC such as designing course books and/or supplementary materials which should be in line with the principles of the new curriculum. Learners also need to contribute to material and task design by introducing self-prepared materials to the learning material and perform as reflective individuals in their own learning. Considering the roles of stakeholders in the implementation of NELC, it is believed that the main goal: fostering learners to be effective communicators in English would be successfully achieved.

\subsubsection{The organization of the curriculum}

The NELC adopts comprehensive approach to language teaching and learning methods in the curriculum development by integrating various teaching techniques and learning tasks to the curriculum. Moreover, the selection was tried to be completely in accordance with the theme as well as the language functions introduced in each unit. The curriculum is divided into 10 units arranged around interrelated themes or topics for each grade. Thematic units are presented to encourage learners to associate with what they have learnt.

\subsubsection{Instructional design}

The curriculum can be considered to have a 'multi-syllabus' since it integrates various components of other syllabus types. Additionally, the approach adopted in the curriculum includes most components of functional syllabus and skill-based syllabus with the integration of other language aspects: vocabulary, structure, and pronunciation related to the units arranged based on themes, functions, and skills.

\subsubsection{Instructional materials}

The NELC strongly suggests the use of authentic materials in all grades. There is no sequencing in the order of the suggested teaching materials since it is topical. Most materials can be presented both online and offline, with multimedia or print. 
Additionally, there are additional tasks to engage learners such as discussion time, idioms/proverbs of the week, tech pack, E-portfolio entry, and video blog entry.

\subsubsection{Assessment}

The assessment used is a combination of alternative, traditional, and electronic assessment types. For example, to evaluate speaking/listening skills can be done through Discussion Time activities and/or Video Blogs (V-logs), meanwhile to assess integrated four skills can be carried out via Tech Pack, pen-paper in-class exams, or E-portfolios. Moreover, E-portfolios is believed as one of assessment strategies to extend the scope of materials and activities that can be carried out to assess learners' language performance. Employing many types of assessment offered thus may help teachers gain more information about learners' learning progress. It is suggested that whichever assessment tool is employed, the emphasis should be clearly given to designing communicative assessment tasks and evaluating language production in the curriculum implementation.

\subsection{Analysis of the Commonalities and Differences shared between Indonesia's 2013 EFL Curriculum and Turkey's NELC}

\subsubsection{Commonalities}

Both Indonesia's 2013 EFL Curriculum and the New $9^{\text {th }}-12^{\text {th }}$ grades English language Curriculum (NELC) in Turkey designed for secondary schools focus on learner-centeredness. Indonesia's 2013 EFL Curriculum is intended to focus on learners to be pious, noble, confident, and successful individuals, and effective communicators in English. NELC is also focused on encouraging learners to be autonomous, productive, and successful individuals who are able to effectively, fluently, and accurately communicate in English. Additionally, NELC has following intentions: 1) to build learners' self-awareness, self-expression, individual, social, and cultural development; (2) to promote collaborative learning; (3) to share responsibility; and (4) to be effective and interactive in classroom environment (Kondakç1, 2014). Given that this is in accordance with Richards (2001) that it is essential when it comes to learner-centeredness in the learning since learners try to develop their role of individual experience, the need to develop individual needs, awareness, self-reflection, critical thinking, strategies, and other qualities and skills.

Additionally, the two curricula also share the similar main goal which is to develop learners' language competence: communicative skills. Students are expected to communicate in English in the classroom at all times; so that their communicative competence can be enhanced. They also need to actively practice all four language skills and participate during communicative activities (MEB-TTKB, 2014). Therefore, not only teachers, students also need to contribute to the success of achieving the main goal by considering their roles in the implementation of the curriculum.

\subsubsection{Differences}

The differences of the two curricula lie in the instructional design, instructional materials, and assessment. In terms of instructional design, 2013 EFL Curriculum 
rather employs text-based syllabus since it uses genre-based approach in the learning to achieve the main aim which is fostering learners' communicative skills through the use of texts. Meanwhile, the instructional design used in the NELC can be considered as "multi-syllabus" since it provides various components of other syllabus types. The approach employed in the curriculum includes elements of mostly functional syllabus, and skill-based syllabus with the integration of other language aspects: vocabulary, pronunciation, and structures based on the themes, functions, and skills of each unit designed.

Additionally, what differs the two curricula is instructional materials. 2013 EFL Curriculum provides texts (interpersonal, transactional, and functional), and language functions to teach to students to build their communicative skills with material sequencing. However, the NELC rather suggests themes, functions, and skills without material sequencing. Additionally, it strongly recommends other tasks: idioms/proverbs of the week, discussion time, tech pack, e-portfolio entry, and video blog entry.

In assessing students' performance, 2013 EFL Curriculum emphasizes on authentic assessment including performance, project, product, paper and pen, portfolio, behaviour, and self-assessment. Meanwhile, the NELC employs a mixture of alternative, traditional, and electronic assessment types. Additionally, it suggests evaluating listening/speaking skills via Discussion Time activities and/or Video Blogs (V-logs) and evaluating integrated four skills as well as other language aspects (lexis, structure, and pronunciation) via Tech Pack, pen-paper in class exams, or E-portfolios.

Considering the commonalities and differences shared between the curricula, there is potential future improvement in Indonesia's education quality, for instance, by providing technology-enhanced materials and assessments to make the teaching and learning easier, enjoyable, and engaging.

\section{Conclusion}

It can be concluded that Indonesia's 2013 EFL Curriculum and Turkey's NELC share commonalities in terms of the main goal of the learning: developing learners' communicative skills, and focusing on learner-centeredness in the teaching-learning process. However, the differences lie in their instructional design, instructional materials, and assessment. 2013 EFL Curriculum adopts text-based syllabus while the NELC adopts 'multi-syllabus' (mostly functional syllabus and skill-based syllabus). In instructional materials, 2013 EFL Curriculum focuses on texts and language functions with sequencing while the NELC offers various topical materials with no sequencing. Moreover, 2013 EFL Curriculum emphasizes authentic assessments while the NELC employs a mixture of alternative, traditional, and electronic assessment types. Given that Indonesia may learn from Turkey, for example, by considering technology-enhanced instructions, materials, and assessments for a better improvement in education quality in the future.

Since the study only employed document analysis to analyse EFL curricula, potential future studies may employ interviews and observation to gain more data. 
Interviews with English teachers may be conducted to explore how they reflect on the concept and implementation of EFL curricula in both countries. Additionally, interviews with students may be carried out to explore their voices in the curricula they have experienced. Furthermore, an observation may be conducted to see the actual implementation of the curricula employed.

\section{References}

Brown, J. E. (1994). How to Write Rationale. SLATE Starter Sheet, NCTE.

Chege, E. W. (1999). Reading comprehension and its relationship with academic performance in rural Machakos. Nairobi: Kenyatta University. Retrieved [April 18, 2017] from: http://ir-library.ku.ac.ke/handle/ 123456789/3722

Hurriyet Daily News. (2017). Turkey's education ministry prepares curriculum overhaul. Retrieved [April 17, 2017] from: http://www.hurriyetdailynews.com/ turkeys-education-ministry-preparescurriculum-overhaul.aspx?pageID=2 38\&nID $=108015 \&$ NewsCatID $=341$

Istiqomah, F. (2013). A comparison study of Australian and Indonesian English curriculum for upper primary school. Lingua Scientia, 5(2). Retrieved [April 20, 2017] from: http://id.portalgaruda.org/index.php?ref=browse $\&$ mod=viewarticle $\&$ article $=253567$

Kondakç1, N. (2014). A comparative analysis of national and international English language curricula for high schools in Turkey. Ankara: The Graduate School of Education of Bilkent University. Retrieved [April 16, 2017] from: www.thesis.bilkent.edu.tr/0006634.pdf

Mardjuki, M. S. (2018). English teachers' perception on the use of authentic assessment in 2013 curriculum. IJELTAL (Indonesian Journal of English Language Teaching and Applied Linguistics), 2(2), 151-163. Retrieved [May 22, 2018] from: http://ijeltal.org/index.php/ijeltal/article/view/95

Mendez-Shanoon, E. C. (2010). "We will always be in the shadows" - a qualitative descriptive study of undocumented Latino immigrants surviving in the United States. University of Iowa. Retrieved [November 12, 2016] from: http://ir.uiowa.edu/etd/555.

Miles, M. B., \& Huberman, A. M. (1984). Qualitative data analysis: A sourcebook of new methods. California: SAGE Publications Inc.

Nation, I. S. P., \& Macalister, J. (2010). Language curriculum design. New York: Routledge, Taylor and Francis Group.

Nulty, D. D. (2012). Curriculum design. Learning, teaching and higher education research. Griffith Institute for Higher Education.

OECD. (2016). PISA 2015 results in focus. Organisation for Economic Co-operation and Development (OECD).

Ornstein, A. C., Levin, D. U., Gutek, G. L., \& Vocke, D. E. (2011). Foundations of education. USA: Wadsworth CENGAGE Learning.

Posner, G. J. (1992). Analyzing the curriculum. New York: McGraw-Hill, Inc.

Prideaux, D. (2003). ABC of Learning and Teaching in Medicine: Curriculum Design. BMJ, Vol. 326. 
Richards, J. C. (2001). Curriculum development in language teaching. USA: Cambridge University Press.

$\mathrm{Su}, \mathrm{S}$. (2012). The various concepts of curriculum and the factors involved in curricula-making. Journal of Language Teaching and Research, 3(1), 153158. doi:10.4304/jltr.3.1.153-158

Suarman, A. (2011). The comparison between Indonesian 2004 CBC and Philippine 2011 SEC of English. Retrieved [April 14, 2017] from: https://www.academia.edu/3082705/The_comparison_of_English_Curriculum _of_Indonesian_and_Philiphine

T.C. Millî Eğitim Bakanlığı, Talim ve Terbiye Kurulu Başkanlığı (MEB-TTKB). (2014). Ortaögretim ingilizce dersi $(9,10,11$ ve 12. siniflar) ögretim programı (Secondary English course of 9th, 10th, 11th and 12th grades curriculum). Ankara: T.C. Millî Eğitim Bakanlığı, Talim ve Terbiye Kurulu Başkanlığı (Republic of Turkey, Ministry of National Education, Education and Training Boards).

Tabari, A. G. (2013). Challenges of language syllabus design in EFL/ESL context. Journal of Language Teaching and Research, 4(4), 869-873. Finland: Academy Publisher. Retrieved [March 6, 2017] from: www.academypublication.com/issues/past/jltr/vol04/04/29.pdf

The Ministry of Education and Culture Regulation of Indonesia No. 69 Year 2013 on the Basic Framework and Curriculum Structure of Senior High Schools.

The Ministry of Education and Culture Regulation of Indonesia No. 21 Year 2016 on Standard of Content for Primary and Secondary Education.

Zacharias, N. T. (2012). Qualitative research methods for second language education: A coursebook. UK: Cambridge Scholars Publishing. 